\title{
The Study on the Development of Teaching Abilities of College English Teachers from the Perspective of Ability Standard
}

\author{
Long Yan \\ Basic Teaching Department \\ Chengdu Aeronautic Polytechnic \\ ChengDu, China
}

\begin{abstract}
At present, there are many problems in English education in higher vocational colleges the most critical of which is that the students' practical ability is poor, causing the difficulty in adapting to the needs of the social development and the future employment of students. Based on the competencybased education, this paper analyzes the connotation of ability standard, probes into the advantages of ability based English education in higher vocational education and puts forward some teaching suggestions hoping to improve the practical ability of students' English and lay a good foundation for the future development of students.
\end{abstract}

Keywords-Higher vocational English education;
connotation; strategy

\section{INTRODUCTION}

With the development of economic globalization, English vocational education has received extensive attention. Although English education has been added to basic education in schools in China, because of the high demand for English professionals in the market, higher vocational English education is still a popular major in Vocational education. However, English education in Higher Vocational Colleges in China is generally out of touch with social needs and can not meet the market demand, which ultimately leads to the unsatisfactory employment prospects of English majors. Combining the direction of study with the demand of the market can lay a good foundation for students'future employment. Therefore, higher vocational English teaching should change teaching concept, rationally set up curriculum content, optimize curriculum structure, take practical application as the criterion, cultivate students'practical ability to meet the needs of enterprises and improve students' employment ability. Relevant research shows that the concept of competency-based education, which focuses on cultivating students'practical abilities, plays an important role in promoting students' practical ability to use English. In the process of English teaching in Higher Vocational colleges, the concept of competency-based education requires teachers to change the concept of English teaching and understand the spiritual connotation of competency-based education.

\section{THE CONNOTATION OF ABILITY-BASED TEACHING CONCEPT}

competency based education (CBE) refers to the teaching system of organizing curriculum and teaching around the knowledge, skills and abilities required by vocational posts. Today's vocational education thought comes from competency-based education. Ability-based education differs significantly from traditional basic education in order to meet the market demand. Students are required to have the necessary practical ability besides basic knowledge. This is an education based on job demand. This mode of education has been highly praised in the West. China introduced this educational ideal in the 1990s. The competency-based educational concept meets the requirements of higher vocational education and is in line with the educational requirements of "emphasizing practical ability training, reforming personnel training". At the same time, competencybased education has more advantages than traditional vocational education: the content of competency-based curriculum is mainly based on Vocational practice, which combines theoretical learning with practical application, breaking the traditional curriculum based on theory; competency-based education pays attention to developing students 'personality, respecting students' principal position, and emphasizing students 'initiative in learning. This individualized teaching mode embodies the teaching principle of all students and is conducive to the realization of the educational reform concept of "teaching students according to their aptitude" and "giving priority to students". Ability-based education and teaching evaluation is more objective, attaches importance to the formation of the price of training, and weakens the negative impact of performance evaluation. Therefore, the author believes that higher vocational English education can lead to the concept of competency-based education, take improving students 'practical ability as the criterion, formulate practical teaching objectives for students, cultivate students' practical ability to use English, and provide better practical basis for students 'future employment.

\section{SUGGESTIONS ON ENGLISH COMPETENCE- BASED TEACHING IN HIGHER VOCATIONAL COLLEGES}

\section{A. Promoting Teaching Reform with Market Orientation}

Although English education in Higher Vocational Colleges serves the whole country, it is influenced by the influence of Higher Vocational schools. Most of the English majors in higher vocational colleges will choose to work in the school location. Competence-based education attaches great importance to market-oriented vocational education. According to the characteristics of regional economic development, higher vocational English education should flexibly adjust the curriculum content. Higher vocational 
colleges should rationally adjust curriculum settings and optimize teaching structure according to regional market changes, employment needs and talent needs. Higher vocational colleges should organize professionals to track the changes of talent demand in the employment market, establish market-oriented English major settings, radiate regional English service industries, and enhance the employment ability of graduates. At the same time, higher vocational colleges should also strengthen cooperation with enterprises, give full play to the guiding role of local leading enterprises, and strengthen the market-oriented construction of English majors. In addition, higher vocational colleges should also strengthen cooperation with government. For example, we should strengthen the cooperation with the competent educational authorities, speed up the progress of vocational qualification examinations such as English teacher qualification certificates, strengthen the cooperation with the labor security departments, speed up the pace of vocational skill appraisal, strengthen the cooperation with personnel exchange service institutions at all levels, and accelerate the pace of conformity with the English market. Oriented personnel training.

\section{B. Promoting the Course Reform Guided by Enterprises}

Curriculum reform is not only the core and key to improve the social adaptability of English in Higher Vocational colleges, but also the key work of educational reform. In the reform of English curriculum in Higher Vocational colleges, the concept of competency-based education points out its direction. Competence-based education requires that vocational education should strengthen school-enterprise cooperation in order to improve students 'employment ability. The curriculum reform of English majors in higher vocational colleges should actively cooperate with enterprises, develop courses together with leading local enterprises, highlight the comprehensive requirements of English posts such as listening, speaking, reading and writing, cultivate students 'comprehensive abilities, attach importance to cultivating practical abilities, gradually increase the content of practical courses, and thus improve the quality of teaching. At the same time, we should speed up the construction of excellent English courses, change the concept of English teaching, reform the teaching methods of English courses, take students as the main body, take learning as the goal, let students learn by doing, use in learning, and integrate "teaching, learning and using" in order to improve students "practical ability. In addition, we should speed up the reform of textbooks, focusing on the reform of English textbooks. Work with enterprises, education departments and labor authorities to optimize the content of textbooks, develop textbooks in close connection with local production practices, and ensure that high-quality textbooks are introduced into English education in order to create an efficient classroom. Of course, in the network era, higher vocational English education should also provide students with online learning resources. Emphasis should be placed on the development and use of web-based teaching resources, and new teaching methods such as microclass, flip-over class and web-based courseware should be used to promote the sharing of teaching resources, expand the scope of English learning, and enable students to carry out English learning at anytime and anywhere so as to improve the benefits of high-quality teaching resources and further enhance students 'learning level.

\section{Promoting Teaching Reform Based on Practice}

There are obvious differences between higher vocational education and other higher education. Higher vocational education attaches great importance to students 'practical ability, which coincides with the connotation of competencybased teaching. Competence-based education has strong practical characteristics. Compared with theoretical learning, competence-based education pays more attention to social practice. Under the concept of competence-based education, higher vocational English education should provide more opportunities and platforms for students to practice. In the reform of English teaching in Higher Vocational colleges, we should attach importance to the consistency of teaching content and market demand, combine theoretical learning with enterprise practice, and explore the integration of teaching and practice. At the same time, we can also carry out the "orderbased" training, vigorously promote the combination of work and learning, highlight the practical and professional requirements, increase the proportion of practical courses, implement a series of teaching modes which are conducive to improving students "practical ability, such as "on-the-job practice" and "teacher's help". In addition, we can also establish an English vocational practice system, requiring students to combine work with study, and participate in practice in enterprises for at least 3-6 months each year. We can guide students to carefully analyze the job requirements of employers, learn how to solve problems by colleagues, and actively participate in the process of solving practical problems to enable students to acquire practical abilities in actual positions. Practice-oriented teaching reform essentially means strengthening school-enterprise cooperation, utilizing enterprise staff education resources, optimizing school education, meeting the requirements of competency-based teaching concept, and helping to innovate personnel training methods through School-enterprise cooperation.

\section{Teachers-oriented and Strengthen Team Building}

The teaching level of higher vocational teachers directly affects the teaching quality. Under the competency-based theory, teachers are the promoters and instructors of students 'learning. Through the guidance of teachers' teaching, students realize the market demand of English majors, attach importance to the cultivation of practical ability, and ultimately improve their employment ability. At present, the quality of teachers in Higher Vocational Colleges in our country is uneven, mainly undergraduates and postgraduates, with fewer doctoral students. The difference of educational background will inevitably lead to the gap of teaching level, and ultimately affect the quality of teaching. At the same time, many teachers in higher vocational colleges have rich theoretical knowledge, but their practical ability is relatively low, and teachers lack practical ability, which makes it difficult for teachers to effectively cultivate students 'practical ability, thus affecting the teaching effect. Therefore, strengthening the construction of teachers has become the focus of higher vocational education reform under the concept of competency-based education, as well as English education. To strengthen the construction of teachers in Higher 
Vocational colleges, it is necessary for higher vocational colleges to follow the principles of Vocational Teaching in accordance with market demand, increase the proportion of high-quality English majors, organize teachers to practice in enterprises, help teachers accumulate practical experience, and enhance teachers 'practical ability. Of course, qualified schools can also let business professionals to work in schools, make full use of the practical advantages of business professionals, so that students can more truly feel the way of business work, through classroom reform in schools, simulate the business working environment, in order to improve students 'practical ability. In addition, we should strengthen the construction of teachers 'learning ability, build up a team of learning-oriented teachers, promote teachers to continue learning, let teachers maintain lifelong learning attitude, and establish professional ethics. Focusing on the long-term development, we should take training as a breakthrough to improve teachers 'professional skills, strengthen teacher training, build a group of high-quality teachers, effectively improve the quality of teachers, improve the overall level of teachers, and provide talent guarantee for the long-term development of schools.

\section{E. Pushing forward the reform of Evaluation Guided by evaluation}

In the traditional evaluation of English teaching, teachers tend to focus only on students 'test scores and neglect students' practical abilities. In order to improve English achievement, students usually learn English by rote mechanical memory. After a period, students forget English knowledge completely, which makes the situation of "unemployment after graduation" common. The concept of competency-based education requires that teachers 'teaching evaluation should be "student-oriented", pay attention to student-oriented, and carry out comprehensive evaluation according to students' efforts, cognitive level and practical ability. Therefore, in the evaluation of English teaching in Higher Vocational colleges, teachers can innovate the evaluation model and attract formative evaluation content. The formative evaluation system is a series of problems which are evaluated according to the feedback information of teachers and students in English teaching. In the process of evaluation, students should be guided to actively reflect on their own learning behavior, so that they can self-reflect on their own learning methods, learning efforts, classroom participation, practical performance and other learning processes. Through students 'reflection, students can actively identify their own shortcomings, pick up the remedial network, and constantly improve students' learning ability. 。 Of course, teachers can also use teaching evaluation to adjust teaching strategies in time. According to the problems existing in students 'learning, teachers can timely check the leaks and fill the gaps, adjust the teaching content, increase students' practical opportunities and enhance students 'practical ability, so as to achieve twice the result with half the effort.

\section{THREE, CONCLUDING REMARKS}

As an important subject of Higher Vocational education, English teaching in higher vocational education plays an irreplaceable role in cultivating high-quality English skilled talents in the era of economic globalization. With the development of economy, the social demand for English talents in higher vocational colleges has been increasing, which is both an opportunity and a challenge for English education in Higher Vocational colleges. Higher vocational colleges should recognize the importance of competencybased education, conscientiously implement the teaching requirements of competency-based, market-oriented, strengthen school-enterprise cooperation, take the road of combining work with learning, provide practical talents for the market, and provide talent guarantee for building a well-off society in an all-round way.

\section{REFERENCES}

[1] Little D.Learner Autonomy: A guide for Learners and Teachers [M].Dublin: Authentic, 1991.

[2] Richards J.C, TS.Rodgers.approaches and method in language teaching

[M] .Cambridge: CUP, 1986

[3] DONG Jian-xia, "The Study on the Factors Influencing the Development of Teaching Abilities of College English Teachers: Journal of Heilongjiang College of Education, 2018,37,11, pp. 35-37. 